\title{
Micromorphological and chemical elucidation of the degradation mechanisms of birch bark archaeological artefacts
}

\author{
Sibilla Orsini ${ }^{1}$, Erika Ribechini ${ }^{1 *}$, Francesca Modugno ${ }^{1}$, Johanna Klügl ${ }^{2}$, Giovanna Di Pietro ${ }^{3}$
} and Maria Perla Colombini, ${ }^{1,4}$

\begin{abstract}
Introduction: Since ancient times, the unique properties of birch barks (Betula genus) have made them a material of choice for producing both everyday-life and artistic objects. Yet archaeological birch bark artefacts are rare, and little is known about the chemical transformations undergone by bark (chemically composed mainly of suberin and triterpenes) in archaeological contexts. Understanding the chemical modifications induced by ageing is essential for selecting suitable preservation and conservation approaches. Thus, the main aim of this research is to assess the preservation and state of degradation of archaeological findings made of birch bark: a Neolithic bow case recovered from a melting ice patch in the Bernese Alps (Switzerland) and a waterlogged birch bark vessel discovered at Moossee Lake (Canton of Bern, Switzerland).

Scanning electron microscopy (SEM) and gas chromatography/mass spectrometry (GC/MS) were used to obtain information at micro-morphological and molecular levels on the state of degradation of the birch bark findings. GC/MS analysis followed two different sample preparations, alkaline hydrolysis and solvent extraction, in order to investigate respectively the hydrolysable and soluble constituents, and to test whether part of the suberin structure was depolymerised by the long period of burial.

Results and conclusions: SEM investigations on archaeological birch bark samples have shown that the extent of degradation of the microstructure is much higher in waterlogged birch bark than in birch bark preserved in ice. GC/MS analysis revealed that at a molecular level, the birch bark was quite well preserved. In both the archaeological environments, ice patch and lake water, various reactions had taken place leading to the depletion of reactive and sensitive compounds such as unsaturated acids and epoxy-compounds. In addition, archaeological birch bark had undergone depolymerization and oxidation reactions leading to the appearance of free suberin monomers and of oxidised triterpenes (betulone and lupenone). GC/MS data also seems to suggest that the birch bark preserved in the waterlogged site had a more pronounced degradation both in terms of oxidation and depolymerisation.
\end{abstract}

Keywords: Archaeological birch bark, Suberin, Triterpenes, SEM, GC/MS, Oxidation, Depolymerisation

\section{Introduction}

Birch bark is obtained from several Eurasian and North American birch trees of the genus Betula. The unique physical properties of these barks have made them the material of choice since ancient times for manufacturing artefacts both for the needs of daily life and artistic purposes. Birch bark can withstand changes in shape

\footnotetext{
* Correspondence: erika.ribechini@unipi.it

${ }^{1}$ Dipartimento di Chimica e Chimica Industriale, Università di Pisa, via Moruzzi 3, 56124 Pisa, Italy

Full list of author information is available at the end of the article
}

without breaking, is particularly waterproof, and has biocidal and antioxidant properties. These last features made it useful to past people for food preservation and pharmaceutical purposes. In addition, birch bark was largely used for the manufacture of tar [1,2]. Despite a presumable extensive utilization, at archaeological sites objects made out of birch bark are quite rare. Birch bark objects are preserved for long periods of time only under peculiar burial conditions, such as very dry conditions in arid or cold climates, or wet conditions in sediments and glaciers. In fact, birch bark artefacts used by 
Mesolithic hunter-gatherers were recovered in Germany and objects made by pre-contact hunter-gatherers were recovered from plateau contexts in Canada and at Star Carr (Yorkshire, UK) [3,4]. Horse-mounted nomads (7th to 14th centuries) from Mongolia also used birch bark artefacts [5].

As reported in the literature [6-13], birch bark contains especially high amounts of a waxy hydrophobic substance, called suberin, along with triterpenoids. Chemically the suberin is a bio-polyester and it has been studied and characterised using depolymerisation procedures. Several wet chemical techniques have been used for the depolymerisation of suberin by cleavage of the ester bonds, in order to analyse its monomeric sub-units. The depolymerisation pre-treatment is an essential step for the chemical characterization of this material. The depolymerisation is based on chemical reactions achieving the cleavage of ester bonds: alkaline hydrolysis, trans-esterification or reductive cleavage have been used. The most common procedures are the ester cleavage through alkaline methanolysis ( $\mathrm{NaOMe}$ or $\mathrm{CaO}$ in $\mathrm{MeOH}$ ) and alkaline hydrolysis using hydroalcoholic $\mathrm{KOH}[6,14-16]$. The resulting depolymerisation products, following derivatisation reaction, can be analyzed and identified by gas chromatography coupled to mass spectrometry (GC/MS). The main suberin monomers are long-chain epoxy acids, long-chain $\alpha, \omega$-diacids, and long-chain $\omega$-hydroxyacids, whose yield and variety are dependent on hydrolysis conditions $[11,14]$. Betulin and lupeol together with small amounts of lupenone, betulinic acid and betulone are known to be the main characteristic triterpenoids present in birch bark $[9,10,12,13,17]$.

Little is known about the chemical transformations undergone by bark in archaeological contexts, nor about the chemical composition of the aged materials. To the best of our knowledge, this is the first analytical investigation done on such a subject. The study of the degradation processes undergone by suberin and triterpenes, and of the modification induced by ageing and different burial conditions in archaeological birch bark is essential so that optimal preservation and conservation strategies can be identified.

The discovery of a Neolithic bow case (Figure 1a and Figure 1b) from a melting ice patch in the Bernese Alps of Switzerland was the starting point for our research on archaeological birch bark. The bow case was found between 2003 and 2005, broken in three parts all belonging to the same object, dated by radiocarbon dating back to 2500-2800 BC. The bow case poses a major challenge: made from birch bark, its degradation is as yet unknown and therefore it is unclear how it should be conserved. To get a broader view on birch bark degradation, the ice patch find was compared to a one year old reference sample (Betula pendula) and to the birch bark belonging to a Neolithic (carbon dated 3800 B.C.) waterlogged vessel (Figure 1c). Table 1 reports the list of samples used in this study as well as information on the archaeological objects from which the samples were collected.

The anatomy and the morphology of the cell structure of the birch bark objects were observed by scanning electron microscopy (SEM). Gas chromatography/mass spectrometry (GC/MS) after alkaline hydrolysis, solvent extraction and trimethylsilylation was used to investigate the hydrolysable and soluble constituents and thus to determine the monomer composition of the suberin and the triterpenoid distribution. In addition, to test whether part of the suberin structure was depolymerised by the long period of burial, an analysis of the samples by direct extraction of the organic material with $\mathrm{CH}_{2} \mathrm{Cl}_{2} / \mathrm{MeOH}$, without any alkaline treatments, was also performed.

\section{Results and discussion \\ SEM}

Microscopy observation highlights that outer birch bark consists of numerous cork (phellem) layers. These are composed of two distinct cell types organised in alternate rows (Figure 2a). Regarding the radial crosssections, the first type is characterized by a very broad radial dimension (8 to $12 \mu \mathrm{m}$ ), with thin cell walls $(\approx 1 \mu \mathrm{m})$ and the presence of resin (triterpenoid molecules) in the cell lumina (Figure 2a). The second type is characterized by a very narrow radial dimension (3 to $6 \mu \mathrm{m})$ with thick cell walls $(\approx 3 \mu \mathrm{m})$ (Figure 2a) [18]. The thick-walled phellem cells are heavily suberized [19], whereas the thin walled cells are either little suberized or not suberized at all.

Suberized cells consist typically of a pectin rich middle lamellar layer and of a cellulose sometimes-lignified
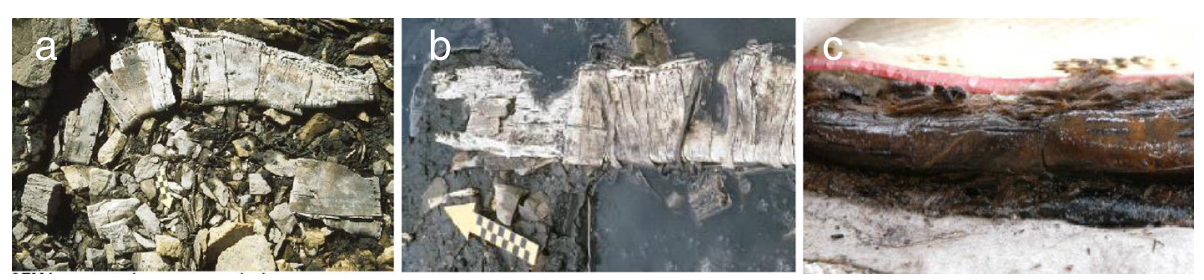

Figure 1 Birch bark objects from which the samples were collected: a) and b) Neolithic bow case conserved in a ice patch; c) Neolithic bark vessel conserved in a waterlogged site. 
Table 1 List of the samples used in this study

\begin{tabular}{lll}
\hline Sample & Description & Location of find \\
\hline 1 & Reference birch bark & Canton Valais, Switzerland \\
2 & Birch bark, bow case (middle section), ice patch & Schnidejoch pass, Bernese Alps, Switzerland \\
3 & Birch bark, bow case (lower section), ice patch & Schnidejoch pass, Bernese Alps, Switzerland \\
4 & Birch bark, vessel, waterlogged site & Moossee Lake, Canton Bern, Switzerland \\
\hline
\end{tabular}

primary wall. The suberin occurs as a distinct lamella deposited on the inner face of the primary cell wall [20]. The cell walls are stable, but the cell layers are becoming tangential separated due to natural weakness. The macroscopic separation of layers (delamination) is given by the different stability of the cell walls and appears in the area of the thin-walled cells or along the boundary between the thin and thick walled cells (Figure 2b). The cells of the cork have an elongated polygonal shape, measure between 60 to $120 \mu \mathrm{m}$, and rest horizontally.

SEM investigations on the archaeological bow case preserved in ice (Samples 2 and 3) showed significant differences in morphological signs of deterioration in terms of the cells present in the different parts of the bow case. The birch bark from the lower section of the bow case (Sample 3) has intact cell walls; no signs of deterioration of the cell walls are visible (Figure 3a). The birch bark looks very similar to the reference bark. On the other side, the SEM analysis of Sample 2 collected from the middle section shows that the thin cell walls, which are slightly suberized or not suberized at all, are extensively degraded and almost absent (Figure 3b). This sample corresponds to an area of the object where macroscopical delamination (separation of layers) is visible.

In the sample from the waterlogged archaeological vessel (Sample 4), the cell walls have become very brittle and fragile, and many ruptures have occurred. In addition, the resin that fills the large birch cells, has almost completely disappeared (Figure 3c).

\section{GC/MS}

To get a clear picture on the chemical transformation mechanisms involving birch bark in archaeological contexts, a reference sample was comparatively studied. The obtained GC/MS profiles were in agreement with the literature [14-16,21,22] and enabled us to interpret and to critically evaluate the data obtained from the analysis of archaeological samples.

The GC/MS profile of reference birch bark (Figure 4) obtained after alkaline hydrolysis is dominated by aliphatic long-chain $\alpha, \omega$-diacids and $\omega$-hydroxyacids (dominant chain-lengths: 16, 18, and 22 carbon atoms),
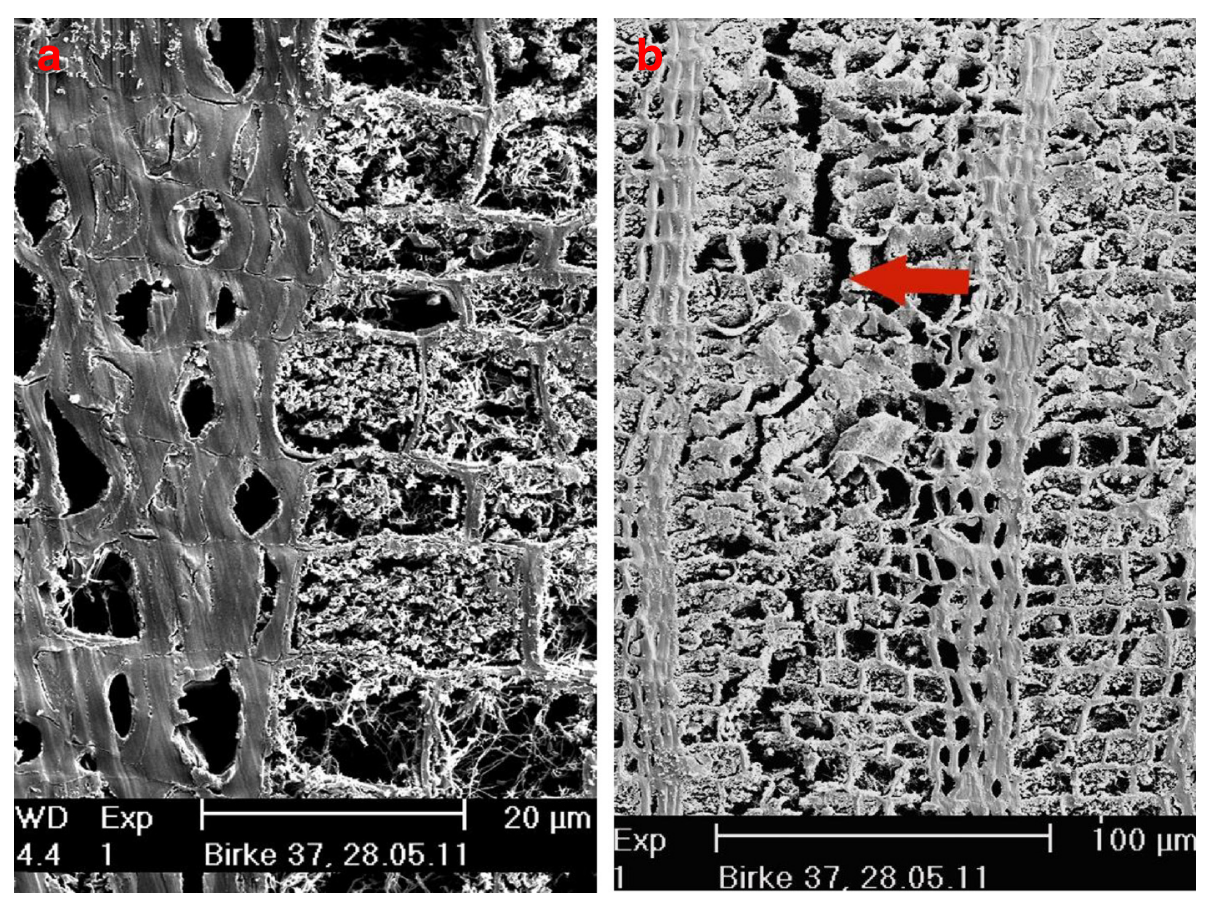

Figure 2 SEM image of Sample 1 (reference birch bark) a) radial cross-section showing two different cell types; b) radial cross-section with initial stages of layer separation. 


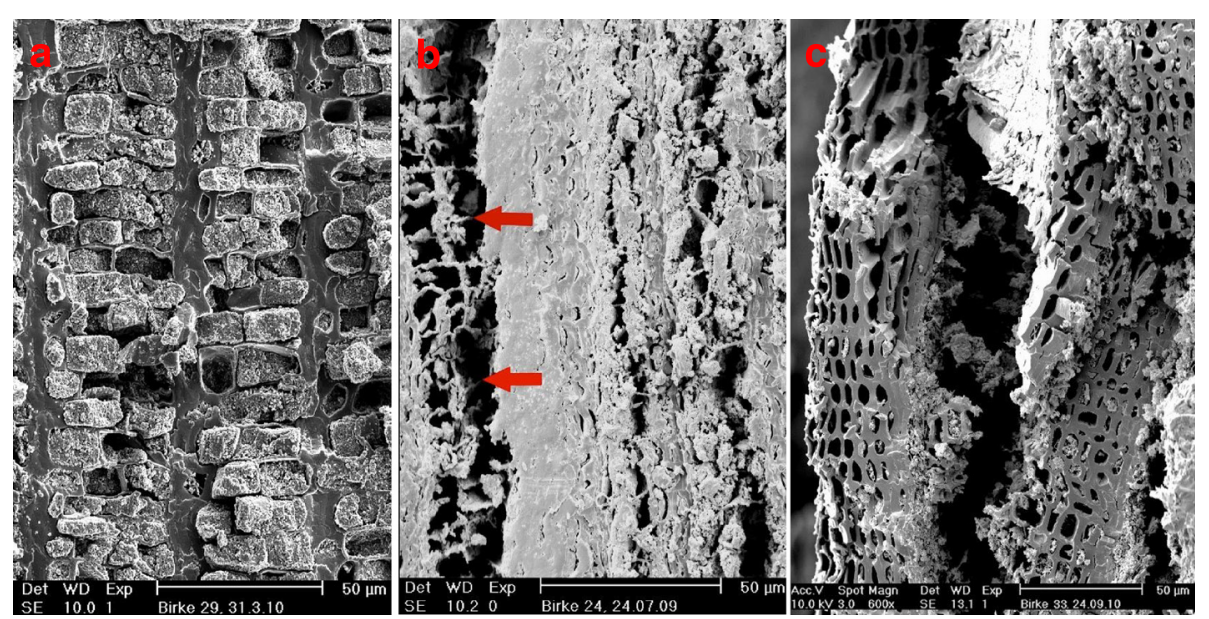

Figure 3 a) SEM image of Sample 3 (archaeological birch bark, lower section, ice patch) radial cross-section showing intact cell walls; b) SEM image of Sample 2 (archaeological birch bark, middle section, ice patch) radial cross-section, extensive degradation of thin cell walls; c) SEM image of Sample 4 (archeological birch bark, waterlogged site) radial cross-section, cell walls became very brittle and fragile with many breakages.

followed by alkanoic acids. In addition, $\omega$-hydroxyacids and $\alpha, \omega$-diacids with mid-chain substituents, such as an unsaturation, an epoxy, or a vic-diol group (peaks 15, 16, $20,23,27,28,29$ and 30 ) are among the main compounds identified. In the alkaline $\mathrm{H}_{2} \mathrm{O} / \mathrm{MeOH}$ hydrolysis condition used to depolymerise the suberin, the epoxy group is converted into corresponding methoxyhydrin compounds (Figure 5). Aromatic components such as trans-ferulic, cis-ferulic and p-coumaric acids are also present. The most abundant triterpene is betulin followed by lupeol, friedelin, betulinic acid and betulone. Table 2 shows the list of suberin monomers and triterpenoids identified by GC/MS.
The archaeological samples (Figures 6,7,8) show a qualitative composition similar to that of the reference birch bark, confirming their identification. However, important differences were found in the quantitative profile of the various samples obtained after the hydrolysis treatment. The histogram of the percentage abundance of the suberin monomers after hydrolysis shows the differences between the quantitative profile of the reference material and the archaeological samples (Figure 9). These data are normalised peak areas and were obtained by dividing by the sum of the areas of the considered peaks in the chromatogram. The abundance of dihydroxy and trihydroxy mono- and di-acids, such as

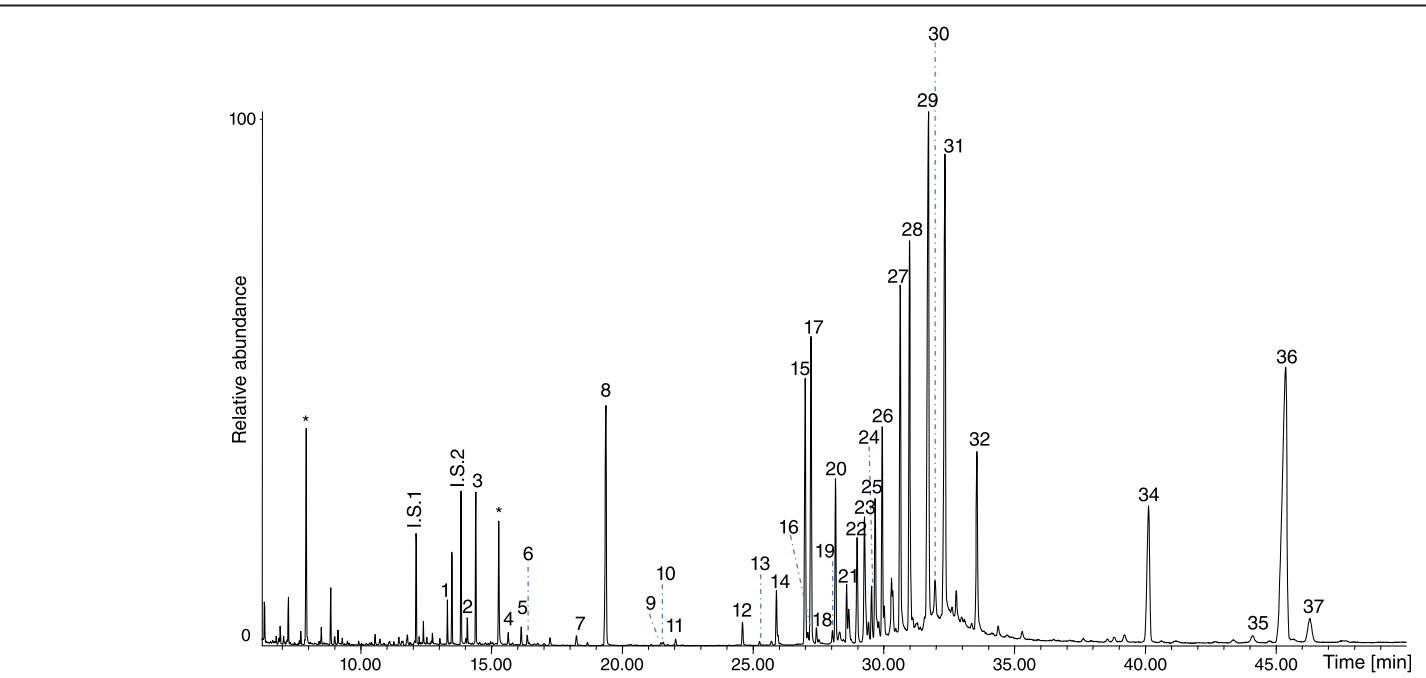

Figure 4 Chromatogram of Sample 1 (reference birch bark) after hydrolysis. I.S.1: internal standard hexadecane, I.S.2 internal standard tridecanoic acid and ${ }^{*}$ instrument contamination. 


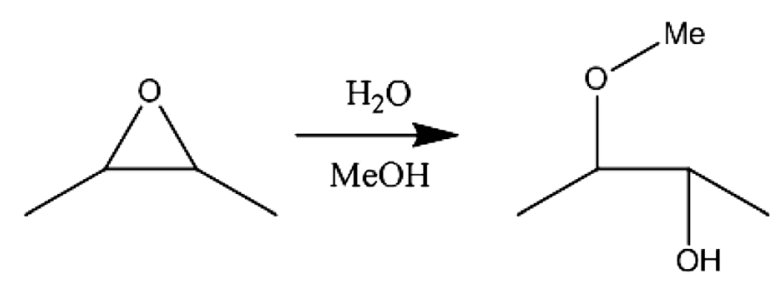

Figure 5 Conversion of epoxy groups during aqueous alkaline hydrolysis.

9,10-dihydroxy-C18:1 acid (peak 23), 9-methoxy-10,18dihydroxy-C18 acid (peak 27), 9,10,18-trihydroxy-C18 acid (peak 28), 9-methoxy-10-hydroxy- (peak 29) and 9,10-dihydroxy-C18- $\alpha, \omega$-dicarboxylic acids (peak 30) is smaller in the archaeological samples than in the reference birch bark. This is due to degradation reactions undergone by the unsaturated fatty acids, hydroxy and epoxy acids during aging. In fact, unsaturated fatty acids can easily react with oxygen leading to the formation of a wide range of compounds, including some with lower molecular weight and higher polarity that can be dissolved by water. Epoxides, reactive due to the ring strain, can react with water leading to the ring opening. In particular, the decrease in 9-methoxy-10,18-dihydroxy-C18 acid and 9-methoxy-10-hydroxy-C18-1,18-dicarboxylic acid can be interpreted as a opening of epoxy rings in the structure during the burial period.

The comparison between the quantitative profile of the two archaeological samples conserved in the ice patch (Samples 2 and 3) reveals a very similar composition of the suberin fraction. The few differences between Samples 2 and 3 refer to the abundance of 9-methoxy-10,18-dihydroxy-C18 acid (peak 27), 9,10,18trihydroxy-C18 acid (peak 28), 9-methoxy-10-hydroxyC18- $\alpha, \omega$-dicarboxylic acid (peak 29) and $\omega$-hydroxy-C22 acid (peak 31). The smaller amount of these compounds in Sample 3 seems to indicate a major degradation in the lower section of the archaeological object conserved in ice compared to the middle section of the same object.

The archaeological sample collected from the vessel conserved in the waterlogged site (Sample 4) shows the greatest signs of degradation due to the small amount of unstable lipid components of the suberin, such as epoxy and unsaturated bonds. In addition, Sample 4 also shows a difference in the profile of triterpenoid compounds (Figure 8). In fact, the presence of lupenone (absent in the other samples) and the increase in the amount of betulone (Figure 10), in comparison with the other two archaeological samples, are indicative of oxidation reactions experienced by triterpenes. It is known that the amounts of lupenone and betulone, naturally present in fresh birch bark only in very small amounts, may increase during degradation as these compounds are the oxidation products of lupeol and betulin, respectively.

The GC/MS analysis of reference birch bark after direct extraction with $\mathrm{CH}_{2} \mathrm{Cl}_{2} / \mathrm{MeOH}$, without the alkaline treatment, did not show the presence of any suberin components. On the other hand, in the extracts of the archaeological samples the following compounds were identified: $\omega-\mathrm{OH}$ C18:1 A (15), $\alpha, \omega-\mathrm{C} 18: 1$ DIA (20), $\omega-$ OH C20 A (26), 9,10,18-tri-OH C18 A (28), $\omega-\mathrm{OH}$ C22 A (31), and $\alpha, \omega-C 22$ DIA (32) (Figure 11 and Table 3). Data reported in Table 3 were obtained integrating the chromatographic peaks and normalizing the resulting areas by the internal standard area (tridecanoic acid, I.S.2) and sample amount The presence of these extractable suberin-derived compounds may be the result of depolymerisation reactions occurred during aging. Although the percentage abundance of free monomers is quite low, the GC/MS data indicates that the original and integral structure of suberin has not been completely preserved in the archaeological materials.

Note that Sample 4, which was collected from the waterlogged site, shows a higher percentage of free suberin-derived compounds than the samples collected from the ice patch. This suggests a more degraded structure for Sample 4, as also highlighted by the results reported above and obtained after hydrolysis of the samples.

\section{Materials and methods \\ Chemicals}

All solvents were Carlo Erba (Milan, Italy) pesticide analysis grade. $n$-Hexadecane (internal standard, $\mathrm{IS}_{1}$ ), tridecanoic acid, (internal standard, $\mathrm{IS}_{2}$ ), hydrochloric acid $(\mathrm{HCl})$, potassium hydroxide $(\mathrm{KOH})$ and $\mathrm{N}, \mathrm{O}-$ bis(trimethyl)silyltrifluoro-acetamide (BSTFA) containing $1 \%$ trimethylchlorosilane, were purchased from Sigma-Aldrich (Milan, Italy).

\section{Reference and archaeological samples}

Two Neolithic artefacts made of birch bark were investigated: a bow case recovered in a ice parch and a vessel recovered in a waterlogged environment (Figure 1). The bow case measures almost 2 meter in length and consists of three parts: an upper part that is the cover of the bow case, and a middle and a lower parts that are the body of the case. Originally the bow case body - middle and lower sections - consisted of one element, that has been separated either through usage or burial period in the ice. The bark used as reference material was collected from a Betula pendula tree in the district of Regensburg (Bavaria, Germany) in April 2011. Table 1 reports the list of reference and archaeological samples used in this study as well as information on the 
Table 2 Compounds identified by GC/MS in reference and in archaeological birch bark

\begin{tabular}{|c|c|c|c|}
\hline $\begin{array}{l}\text { Peak } \\
\text { no. }\end{array}$ & Compound & $\mathrm{m} / \mathrm{z}$ peak & MW \\
\hline 1 & suberic acid & $303,259,217,187$ & 318 \\
\hline 2 & vanillic acid & $312,297,282,267,253$ & 312 \\
\hline 3 & azelaic acid & $317,273,201$ & 332 \\
\hline 4 & sebacic acid & $331,287,215$ & 346 \\
\hline 5 & cis-ferulic acid & $338,323,308,293$ & 338 \\
\hline 6 & p-coumaric acid & $308,293,249,219$ & 308 \\
\hline 7 & palmitic acid & $313,269,145,129,117$ & 328 \\
\hline 8 & trans-ferulic acid & $338,323,308,293$ & 338 \\
\hline 9 & linoleic acid & $337,293,145,129,117$ & 352 \\
\hline 10 & oleic acid & $339,295,145,129,117$ & 354 \\
\hline 11 & stearic acid & $341,297,145,129,117$ & 356 \\
\hline 12 & w-hydroxy-C16 acid & $\begin{array}{l}401,385,311,217,204, \\
147\end{array}$ & 416 \\
\hline 13 & C20 acid & $384,369,145,129,117$ & 384 \\
\hline 14 & $a, \omega-C 16$ dioic acid & $415,299,217,204,147$ & 430 \\
\hline 15 & $\omega$-hydroxy-C18:1 acid & $\begin{array}{l}442,427,411,337 \\
217,204,147\end{array}$ & 442 \\
\hline 16 & $\begin{array}{l}\text { isomer of } \omega \text {-hydroxy-C18:1 } \\
\text { acid }\end{array}$ & $\begin{array}{l}442,427,411,337,217, \\
204,147\end{array}$ & 442 \\
\hline 17 & $\omega, x$-dihydroxy-C16 acid & $\begin{array}{l}489,383,331,317,303, \\
289,275\end{array}$ & 504 \\
\hline 18 & w-hydroxy-C18 acid & $\begin{array}{l}429,413,339,217 \\
204,147\end{array}$ & 444 \\
\hline 19 & C22 acid & $412,397,145,129,117$ & 412 \\
\hline 20 & $a, \omega-C 18: 1$ dioic acid & $456,441,366,276$ & 456 \\
\hline 21 & a,w- C18 dioic acid & $458,443,368,278$ & 458 \\
\hline 22 & unidentified & $515,343,329$ & \\
\hline 23 & 9,10-dihydroxy-C18:1 acid & $515,425,343,329,315$ & 530 \\
\hline 24 & w-hydroxy-C20:1 acid & $\begin{array}{l}470,455,439,365 \\
217,204,147\end{array}$ & 470 \\
\hline 25 & 9,10-dihydroxy-C18 acid & $\begin{array}{l}517,443,359,345 \\
331,303\end{array}$ & 532 \\
\hline 26 & w-hydroxy-C20 acid & $\begin{array}{l}457,441,367,217 \\
204,147\end{array}$ & 472 \\
\hline 27 & $\begin{array}{l}\text { 9-methoxy-10,18-dihydroxy- } \\
\text { C18 acid* }\end{array}$ & $547,332,317,303$ & 562 \\
\hline 28 & 9,10,18- trihydroxy- C18 acid & $605,471,390,317,303$ & 620 \\
\hline 29 & $\begin{array}{l}\text { 9-methoxy-10-hydroxy- } \\
\text { C18-1,18-dioic acid* }\end{array}$ & $551,515,441,317,303$ & 576 \\
\hline 30 & $\begin{array}{l}\text { 9,10-dihydroxy- } \\
\text { C18-1,18-dioic acid }\end{array}$ & $619,545,373,317,303$ & 634 \\
\hline 31 & $\omega$-hydroxy-C22 acid & $485,469,395,217,204$ & 500 \\
\hline 32 & $a, \omega-C 22$ dioic acid & $499,383,217,204$ & 514 \\
\hline 33 & friedelin & $426,411,315,207,189$ & 426 \\
\hline 34 & lupeol & $\begin{array}{l}498,483,393,369 \\
203,189\end{array}$ & 498 \\
\hline 35 & betulone & $422,409,203,189$ & 512 \\
\hline
\end{tabular}

Table 2 Compounds identified by GC/MS in reference and in archaeological birch bark (Continued)

\begin{tabular}{llll}
\hline 36 & betulin & $596,496,483,393$, & 596 \\
& & \\
37 & betulinic acid & 600,189 & \\
& & $203,189,512,483$, & 600 \\
38 & lupenone & $424,409,313,245,205$ & 424 \\
\hline
\end{tabular}

*The epoxy compounds were converted into corresponding methoxyhydrin compounds during hydrolysis in the presence of methanol.

Compounds were identified as TMS ester and ether derivates. Numbers refer to the peak numbers in the chromatograms shown in Figure 4, Figures 6,7,8 and Figure 10.

archaeological objects from which the samples were collected. Dendrochronology and Bayesian modelling of about 25 radiocarbon dates were used to calibrate the radio carbon dating.

\section{SEM}

Comparative visual examination of the microstructure of the radial section was carried out on each sample, using a Philips XL30 SEM scanning electron microscope. Neolithic birch bark samples from a melting ice patch and from a waterlogged burial site were compared with reference samples of 1-year-old birch bark.

Atmospheric freeze-drying at $-20^{\circ} \mathrm{C}$ was used to remove the water from the samples. Samples were manually cut with a razor blade, and sections were mounted with conductive graphite adhesive (Leit-C after Göcke, Plano, Wetzlar, Germany) on an aluminium specimen stub. A conductive metal coating (AU) was applied by sputtering. The SEM examinations were carried out at a voltage of $10 \mathrm{kV}$ and high vacuum $\left(3 \times 10^{-5} \mathrm{mbar}\right)$.

\section{GC/MS}

Analysis of polymerised and soluble components

Sample (3-5 mg) was subjected to alkaline hydrolysis $[23,24]$ by adding $1 \mathrm{~mL}$ of methanolic $\mathrm{KOH}(\mathrm{KOH}$ in $\mathrm{CH}_{3} \mathrm{OH}(10 \mathrm{wt} \%) / \mathrm{KOH}$ in $\left.\mathrm{H}_{2} \mathrm{O}(10 \mathrm{wt} \%), 2: 3\right)$, and heating at $60^{\circ} \mathrm{C}$ for $3 \mathrm{~h}$. After hydrolysis, neutral organic components were extracted with $n$-hexane $(3 \times 500 \mu \mathrm{L})$ and, after acidification with hydrochloric acid $(10 \mathrm{M}$; to $\mathrm{pH} 2$ ), the acidic organic components were extracted from the hydrolysate with diethyl ether $(3 \times 500 \mu \mathrm{L})$. Aliquots of both fractions were evaporated to dryness under a gentle stream of nitrogen and subjected to trimethylsilylation. This was achieved by mixing the dried aliquots with an internal standard solution $(5 \mu \mathrm{L}$ of tridecanoic acid solution, $140 \mu \mathrm{g} \mathrm{g}^{-1}$ ) and derivatising with $20 \mu \mathrm{L}$ of BSTFA (at $60^{\circ} \mathrm{C}, 30 \mathrm{~min}$ ), using $150 \mu \mathrm{L}$ iso-octane as the solvent. After adding $10 \mu \mathrm{L}$ of $n$-hexadecane solution $\left(80 \mu \mathrm{g} \mathrm{g}^{-1}\right)$ as an internal standard for the injection, $2 \mu \mathrm{L}$ of the solution were analyzed by GC/MS. 


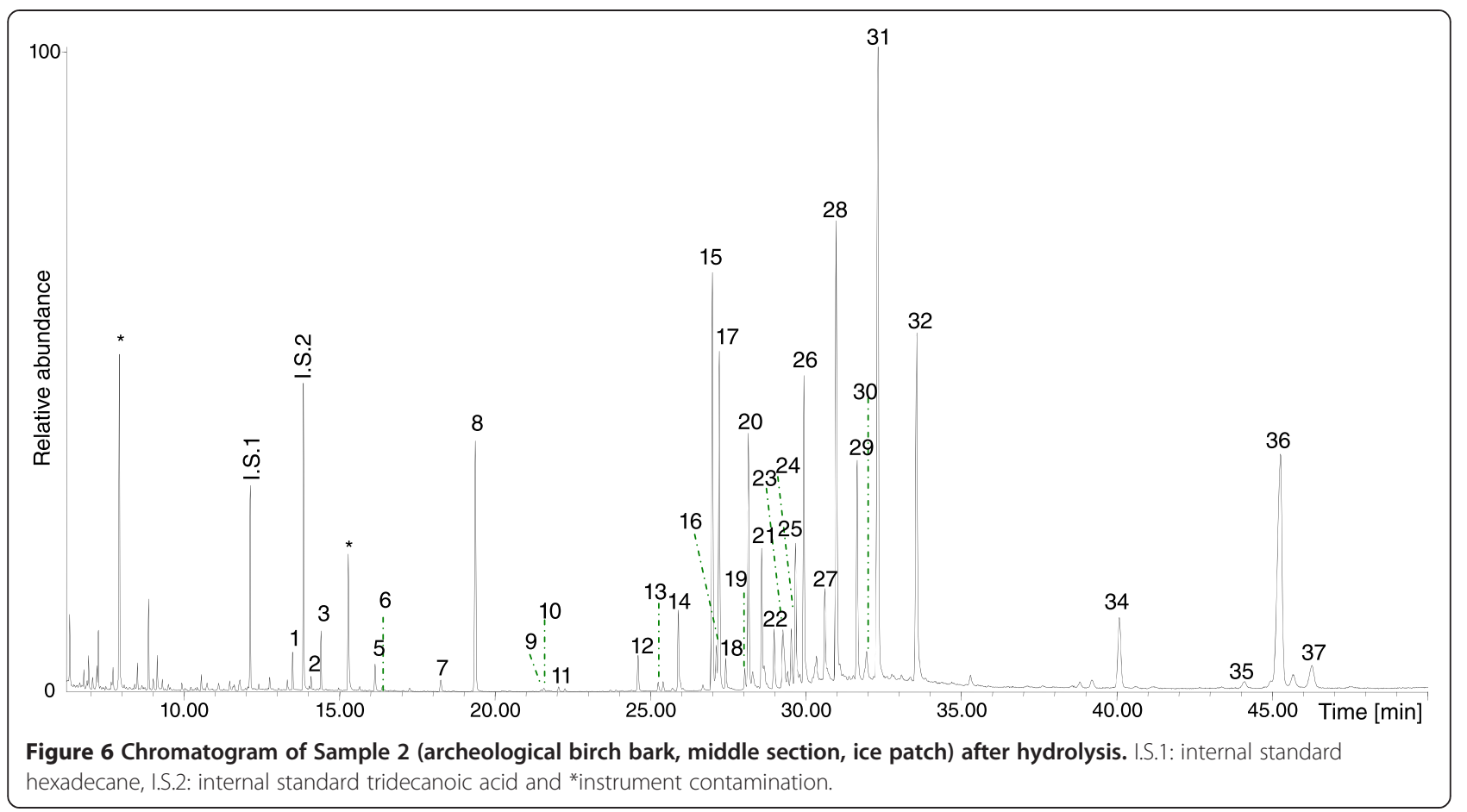

\section{Analysis of extractable components}

Sample (3-5 mg) was subjected to extraction in order to isolate the non-networked and soluble compounds from the birch bark. The samples were extracted three times with $500 \mu \mathrm{l}$ of $\mathrm{CH}_{2} \mathrm{Cl}_{2} / \mathrm{MeOH}$ 3:1 (v/v) in an ultrasonic bath at $60^{\circ} \mathrm{C}$ [17]. The extracts were dried under nitrogen and then subjected to derivatization with BSTFA for GC/MS analysis.

The gas chromatograph system $6890 \mathrm{~N}$ (Agilent Technologies, Palo Alto, CA, USA) was coupled with a 5973

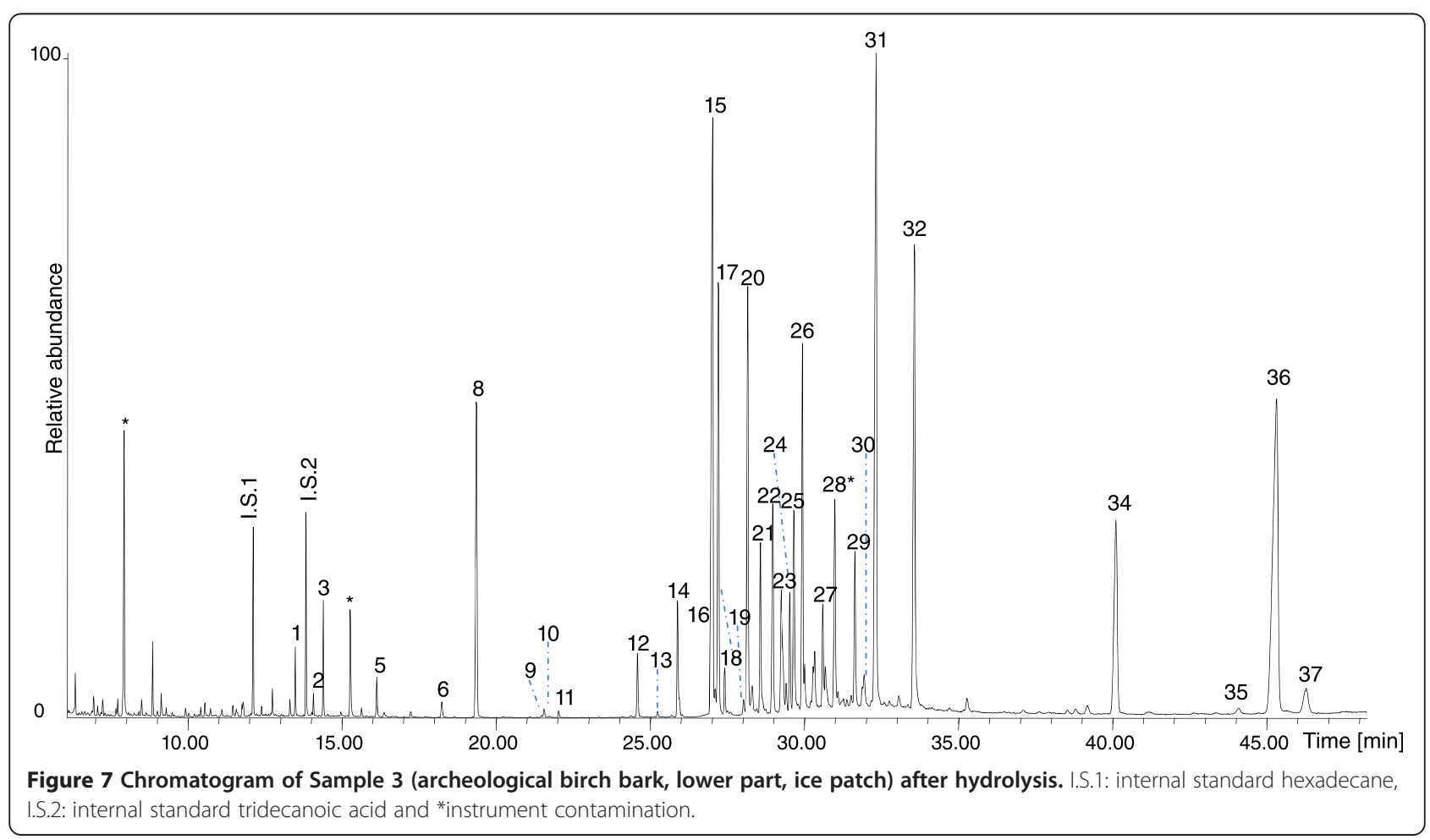




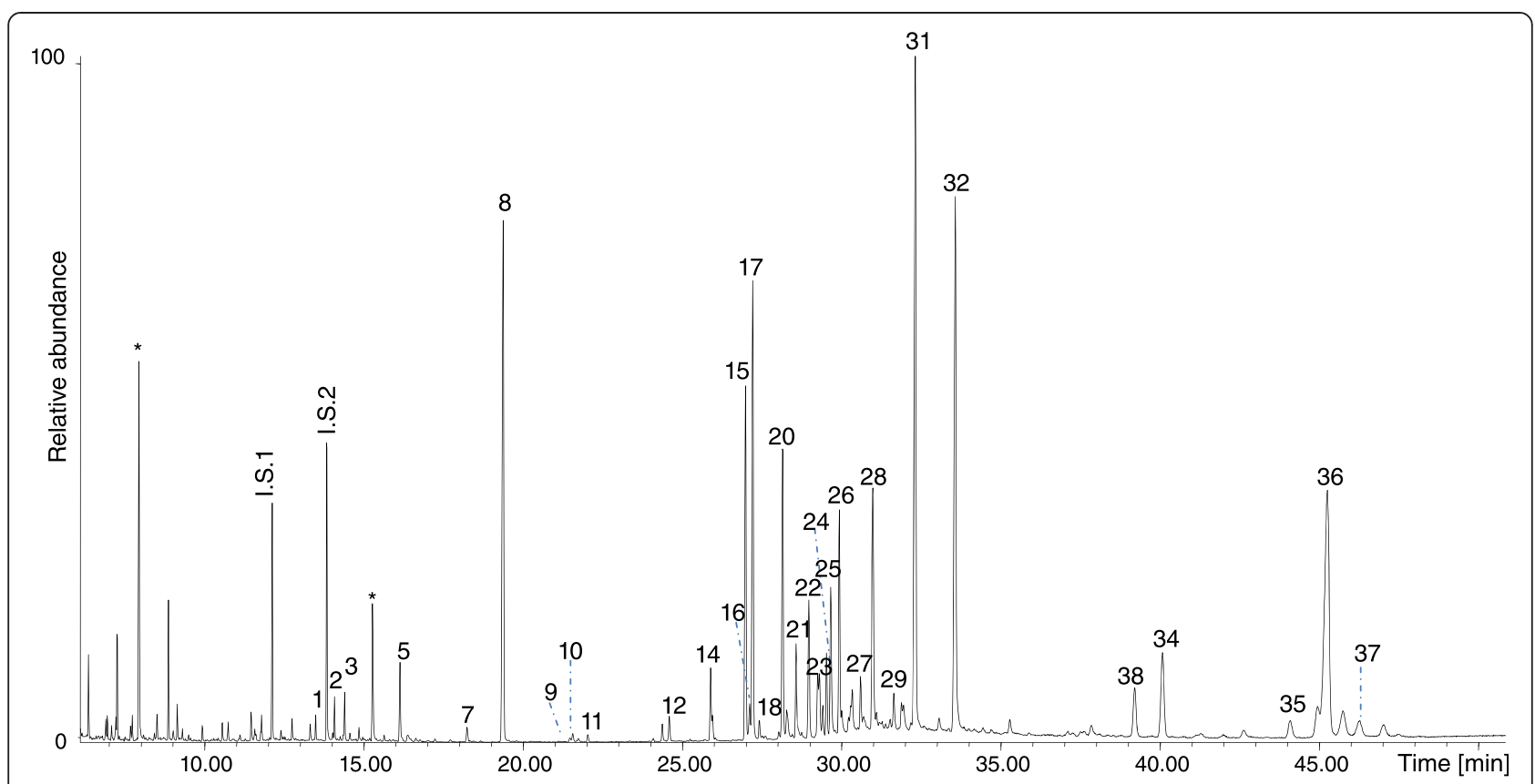

Figure 8 Chromatogram of sample 4 (archeological birch bark, waterlogged site) after hydrolysis. I.S.1: internal standard hexadecane, I.S.2: internal standard tridecanoic acid and *instrument contamination.
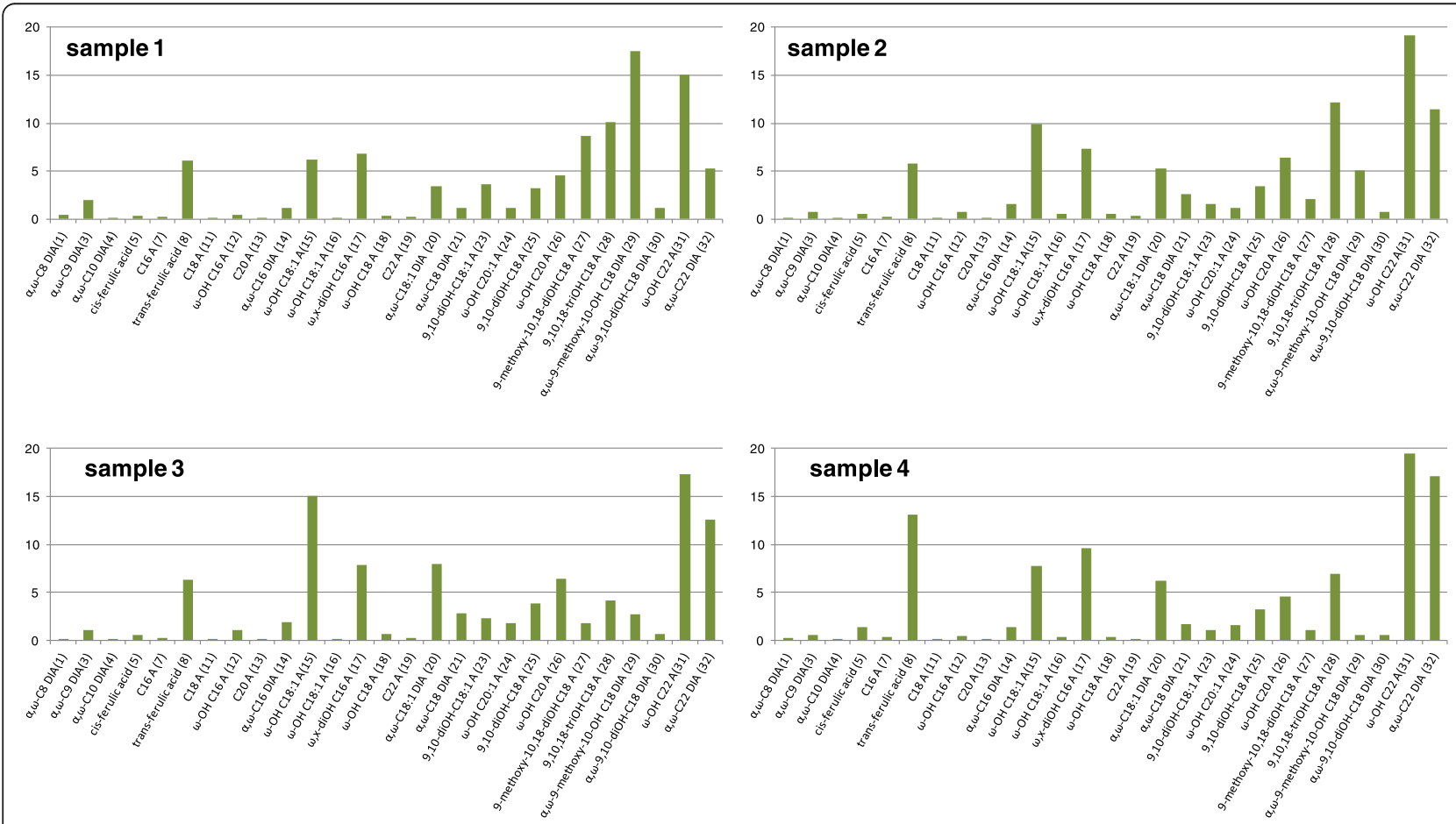

Figure 9 Histogram of suberin monomers (\%) obtained after saponification and GC/MS analysis of Samples 1, 2, 3 and 4. (monocarboxylic acid

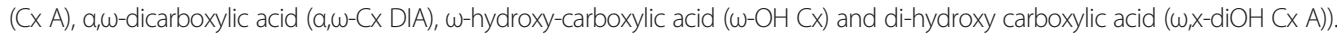




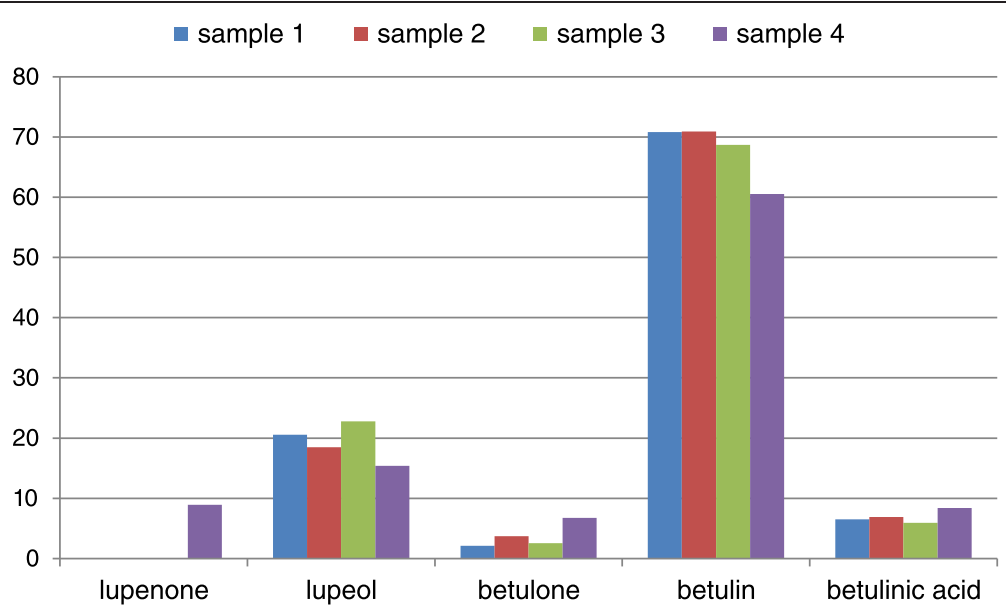

Figure 10 Relative percentage abundance of triterpenes obtained by GC/MS analysis of Samples 1, 2, 3 and 4.

mass selective detector (Agilent Technologies, Palo Alto, CA, USA) single-quadrupole mass spectrometer. For the gas chromatographic separation, an HP-5MS fused silica capillary column (5\%diphenyl-95\% dimethylpolysiloxane, $30 \mathrm{~m} \times 0.25 \mathrm{~mm}$ i.d., J\&W Scientific Agilent Technologies, USA) with a de-activated silica pre-column $(2 \mathrm{~m} \times 0.32 \mathrm{~mm}$ i.d., J\&W Scientific Agilent Technologies, USA) was used. The split-splitless injector was used in splitless mode at $320^{\circ} \mathrm{C}$. The GC/MS parameters for the analysis of the different fractions were as follows: $80^{\circ} \mathrm{C}$ isothermal for $2 \mathrm{~min}, 10^{\circ} \mathrm{C} \mathrm{m^{-1 }}$ up $200^{\circ} \mathrm{C}$ and isothermal

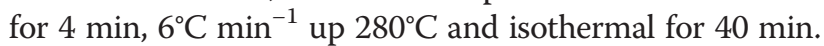
The carrier gas (He, purity 99.9995\%) was used in the constant flow mode at $1.2 \mathrm{~mL} \mathrm{~min}{ }^{-1}$.

Peak assignments were performed using mass spectra interpretation, comparison with mass spectral libraries (NIST 2.0), and with published mass spectra.

\section{Conclusions}

Scanning electron microscopy (SEM) and gas chromatography/mass spectrometry (GC/MS) were used to obtain information at a micro-morphological and molecular level on the preservation and the state of degradation of various birch bark archaeological findings.

Our SEM investigations on archaeological birch bark samples revealed that the extent of degradation of the microstructure was much higher in waterlogged birch bark than on birch bark preserved in ice. However, the two samples from birch bark bow case preserved in the same context of the ice patch, presented significant differences in deterioration at the cell level. In the sample collected from the lower area of the bow case, no evidence of degradation was visible; the cell walls were stable and intact. The sample collected from the middle section, however presented a significant degradation of thin non-suberized cell walls. This involves a great risk of macroscopical separation of the layers (delamination) and creates specific needs in terms of the conservation methodology. The reasons for the different state of preservation of the bow case is still unknown. It could be due to the different qualities of the raw material or repairs (newer parts), or differences in the burial conditions in the ice patch.

GC/MS analysis following two different sample preparations, alkaline hydrolysis and solvent extraction, respectively, was used to investigate the hydrolysable and soluble constituents and, to test whether part of the suberin structure was depolymerised by the long period of burial. GC/MS revealed that at a molecular level all the birch bark objects seemed to be quite well preserved. In the archaeological environments considered, various reactions had taken place leading to the depletion of more reactive and sensitive compounds such as unsaturated acids and epoxycompounds. The archaeological birch bark underwent depolymerization and oxidation reactions leading to the appearance of free suberin monomers, and of oxidised triterpenes such as betulone and lupenone. In addition, GC/MS data seems to suggest that the birch bark preserved in the waterlogged site had a more pronounced degradation both in terms of oxidation and of depolymerisation. In fact, the presence of water may have favoured the hydrolysis reaction, i.e. depolymerisation, and the depletion of compounds bearing sensitive groups such as the epoxy groups via the opening of the ring. All that discussed above comes from considering the burial environments as the major factor that could have influenced the chemical alteration/degradation of the birch bark. However, we can not exclude that such differences pre-existed to the burial of the samples as both the pre-burial and burial history of the samples is unknown. 


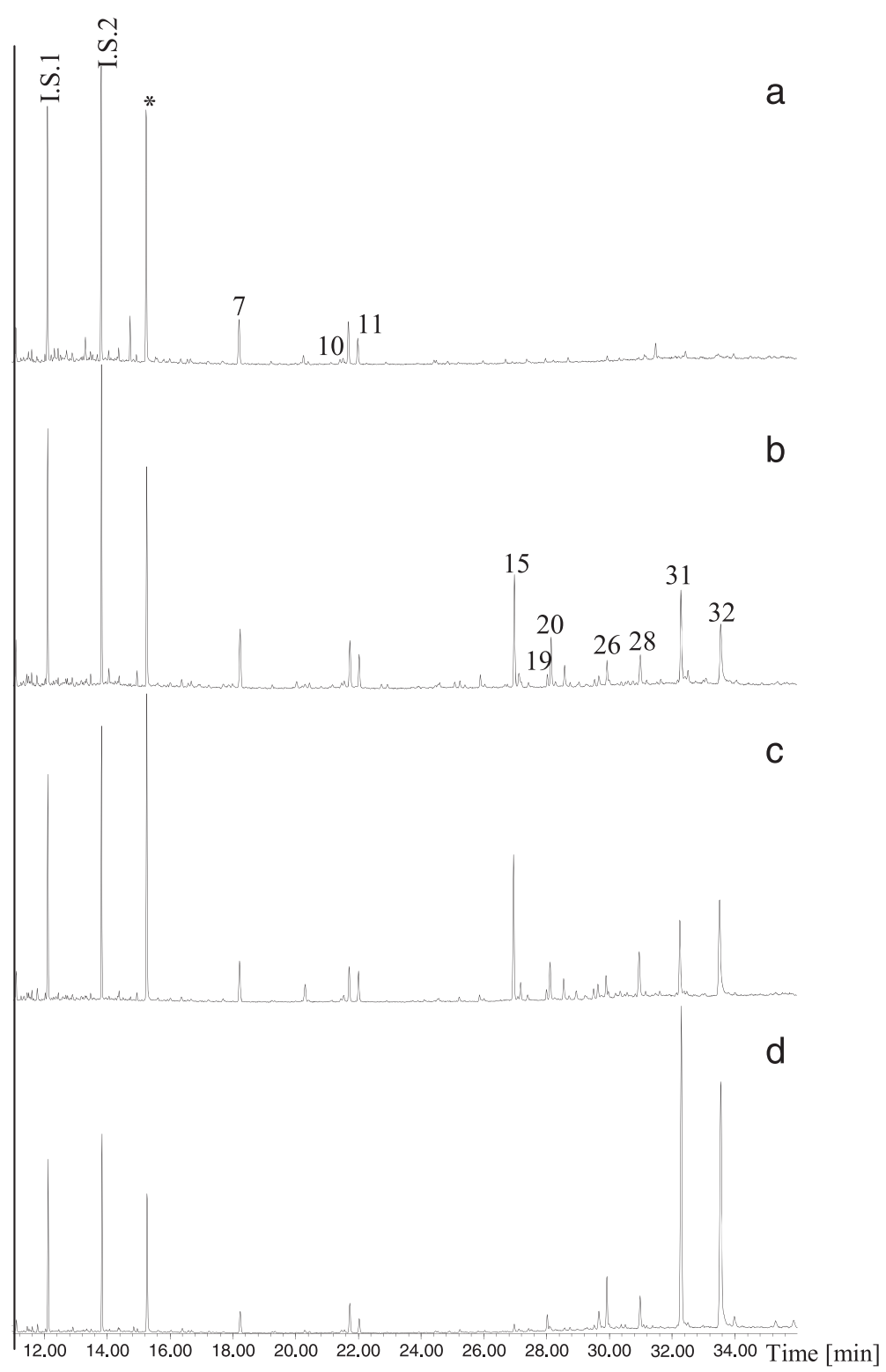

Figure 11 Chromatograms obtained after extraction with $\mathrm{CH}_{2} \mathrm{Cl}_{2} / \mathrm{MeOH}$ of A) Sample 1, B) Sample 2, C) Sample 3 and D) Sample 4.

I.S.1: internal standard hexadecane, I.S.2: internal standard tridecanoic acid and *instrument contamination.

Table $3 \%$ of free suberin-derived compounds in the extracts of samples $1,2,3$ and 4

\begin{tabular}{|c|c|c|c|c|}
\hline Suberin component (\%) & 1 & 2 & 3 & 4 \\
\hline$\omega-\mathrm{OH} \mathrm{C18:1} \mathrm{A} \mathrm{(15)}$ & 0.0 & 0.2 & 0.4 & 0.0 \\
\hline a,w-C18:1 DIA (20) & 0.0 & 0.1 & 0.1 & 0.0 \\
\hline$\omega-\mathrm{OH}$ C20 A (26) & 0.0 & 0.0 & 0.1 & 0.2 \\
\hline 9,10,18-tri-OH C18 A (28) & 0.0 & 0.1 & 0.2 & 0.1 \\
\hline$\omega-\mathrm{OH}$ C22 A (31) & 0.0 & 0.2 & 0.3 & 1.1 \\
\hline$a, \omega-C 22$ DIA (32) & 0.0 & 0.2 & 0.5 & 1.2 \\
\hline sum (\%) & 0.0 & 0.8 & 1.5 & 2.6 \\
\hline
\end{tabular}

If confirmed by the planned analysis of a larger amount of samples, the preservation conditions of the birch bark objects suggest the possibility to perform drying treatments without previous consolidation and to limit consolidation locally avoiding full impregnation.

\section{Competing interests}

The authors declare that they have no competing interests.

\section{Authors' contribution}

JK, ER, FM and GDP conceived this study. JK and GDP performed SEM investigation and interpreted the results. SO performed GC/MS investigation. SO and ER interpreted GC/MS data. ER, GDP, JK and SO wrote the paper. FM 
and MPC critically reviewed the manuscript. All authors read and approved the final manuscript.

\section{Author details}

'Dipartimento di Chimica e Chimica Industriale, Università di Pisa, via Moruzzi 3, 56124 Pisa, Italy. ${ }^{2}$ Archaeological Service of the Canton of Bern, Conservation Department, Bern, Switzerland. ${ }^{3}$ Research Area Materiality in Art and Culture, Bern University of the Arts, Bern, Switzerland. ${ }^{4}$ Institute for the Conservation and Valorization of Cultural Heritage, CNR, Via Madonna del Piano 10, Sesto Fiorentino, Firenze, Italy.

Received: 13 June 2014 Accepted: 9 January 2015

Published online: 20 January 2015

\section{References}

1. Ribechini, E., Direct Mass Spectrometric Techniques: Versatile Tools to Characterise Resinous Materials, in Organic Mass Spectrometry in Art and Archaeology, M.P. Colombini and F. Modugno, Editors. 2009, John Wiley\&Sons Ltd. Chichester (UK). p. 75-95.

2. Modugno, F. and E. Ribechini, GC/MS in the Characterisation of Resinous Materials, in Organic Mass Spectrometry in Art and Archaeology, M.P. Colombini and F. Modugno, Editors. 2009, John Wiley\&Sons, Ltd. Chichester (UK). p. 215-235.

3. Croft S, Mathewes RW. Barking up the Right Tree: Understanding Birch Bark Artifacts from the Canadian Plateau, British Columbia. BC Studies. 2013;180:83-122.

4. Grahame, C., ed. Excavations at Star Carr: An Early Mesolithic Site at Seamer Near Scarborough. 1954, Yorkshire. Cambridge University Press, Cambridge.

5. Törbat, C., D. Batsüch, and T. Ocir Batbajar, Steppenkrieger. Reiternomaden des 7.-14. Jahrhunderts aus der Mongolei. First Edition ed. Das Felsgrab aus Zargalant, Manchan sum, Chovd ajmag. 2012, Germany.

6. Ekman R. The Suberin monomers and triterpenoids from the Outer Bark of Betula verrucosa Ehrh. Holzforschung. 1983;37(4):205-11.

7. Holloway PJ. The composition of suberin from the corks of Quercus suber L. and Betula pendula roth. Chem Phys Lipids. 1972;9(2):158-70.

8. Bernards MA. Demystifying suberin. Can J Bot. 2002;80(3):227-40.

9. Cole BJW, Bentley MD, Hua Y. Triterpenoid extractives in the Outer Bark of Betula lenta (Black Birch). Holzforschung. 1991;45(4):265-8.

10. Cole BJW, Bentley MD, Hua Y, Bu L. Triterpenoid constituents in the Outer Bark of Betula alleghaniensis (Yellow Birch). J Wood Chem Technol. 1991;11(2):209-23.

11. Graça J, Santos S. Suberin: a biopolyester of plants' skin. Macromol Biosci. 2007;7(2):128-35.

12. Huaa Y, Bentley MD, Cole BJW. Triterpenes from the Outer Bark of Betula nigra. J Wood Chem Technol. 1991;11(4):503-16.

13. O'Connell MM, Bentley MD, Campbell CS, Cole BJW. Betulin and lupeol in bark from four white-barked birches. Phytochemistry. 1988;27(7):2175-6.

14. Lopes MH, Gil AM, Silvestre AJ, Neto CP. Composition of suberin extracted upon gradual alkaline methanolysis of Quercus suber L. Cork. J Agric Food Chem. 2000;48(2):383-91.

15. Cordeiro N, Belgacem MN, Silvestre AJ, Pascoal Neto C, Gandini A. Cork suberin as a new source of chemicals.: 1. Isolation and chemical characterization of its composition. Int J Biol Macromol. 1998;22(2):71-80.

16. Gandini A, Pascoal Neto C, Silvestre AJD. Suberin: a promising renewable resource for novel macromolecular materials. Prog Polym Sci. 2006;31(10):878-92.

17. Modugno F, Ribechini E, Colombini MP. Chemical study of triterpenoid resinous materials in archaeological findings by means of direct exposure electron ionisation mass spectrometry and gas chromatography/mass spectrometry. Rapid Commun Mass Spectrom. 2006;20(11):1787-800.

18. Jensen, $W$. The connection between the anatomical structure and chemical composition and the properties of outer bark of White Birch. Vol. 15. 1949.

19. Pollard M, Beisson F, Li Y, Ohlrogge JB. Building lipid barriers: biosynthesis of cutin and suberin. Trends Plant Sci. 2008;13(5):236-46.

20. Schönherr J, Ziegler $\mathrm{H}$. Water permeability of Betula periderm. Planta. 1980;147(4):345-54.

21. Bento MF, Pereira H, Moutinho AMC, van den Berg KJ, Boon JJ, van den Brink OF, et al. Fragmentation of suberin and composition of aliphatic monomers released by metahnolysis of cork from Quercus suber L., Analysed by GC-MS, SEC and MALDI-MS. Holzforschung. 2001;55:487-93.
22. Graça J, Pereira H. Suberin structure in potato periderm: glycerol, long-chain monomers, and glyceryl and feruloyl dimers. J Agric Food Chem. 2000;48(11):5476-83.

23. Modugno F, Ribechini E, Colombini MP. Aromatic resin characterisation by gas chromatography-mass spectrometry: Raw and archaeological materials. J Chromatogr A. 2006;1134(1-2):298-304.

24. Ribechini E, Pérez-Arantegui J, Colombini MP. Gas chromatography/mass spectrometry and pyrolysis-gas chromatography/mass spectrometry for the chemical characterisation of modern and archaeological figs (Ficus carica). J Chromatogr A. 2011;1218:3915-22.

\section{Publish with ChemistryCentral and every scientist can read your work free of charge \\ "Open access provides opportunities to our colleagues in other parts of the globe, by allowing anyone to view the content free of charge." \\ W. Jeffery Hurst, The Hershey Company.}

- available free of charge to the entire scientific community

- peer reviewed and published immediately upon acceptance

- cited in PubMed and archived on PubMed Central

- yours - you keep the copyright

Submit your manuscript here:

http://www.chemistrycentral.com/manuscript/<smiles>c1ccccc1</smiles>

Chemistry Central 